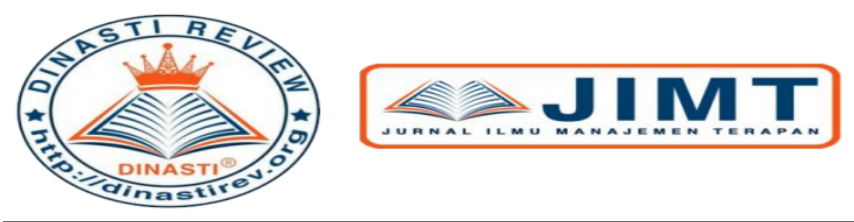

+62 878-9658-6407

087896586407

https://dinastirev.org/JIMT editor@dinastirev.org

\title{
PENDEKATAN QSPM SEBAGAI DASAR PERUMUSAN STRATEGI PENINGKATAN PENDAPATAN ASLI DAERAH KOTA PADANG SIDIMPUAN
}

\section{Erwin Hotmansyah Harahap}

Program Doktoral manajemen, Universitas Putra Indonesia "YPTK" Padang.

\begin{tabular}{|c|c|}
\hline $\begin{array}{l}\text { ARTICLE INFORMATION } \\
\text { Received: 01/09/2019 } \\
\text { Revised: 11/09/2019 } \\
\text { Issued: } 21 \text { September } 2019 \\
\text { (filled in by Editor) } \\
\\
\text { Corresponding Author: Erwin } \\
\text { E-mail: erwinhrp5@ gmail.com }\end{array}$ & $\begin{array}{l}\text { Abstrak: Tujuan dari penelitian ini adalah untuk } \\
\text { menganalisis strategi peningkatan Pendapatan Asli } \\
\text { Daerah (PAD) dan pengaruhnya terhadap peningkatan } \\
\text { pendapatan daerah. Penelitian ini dilakukan pada } \\
\text { Pendapatan Pemerintah Daerah Kabupaten atau Kota } \\
\text { Padangsidimpuan. Penelitian ini juga ingin mengetahui } \\
\text { bahwa strategi PAD didasarkan pada potensi dan } \\
\text { peluang. Analisis menggunakan IFE, EFE, SWOT, dan } \\
\text { kemudian QSPM untuk memilih formulasi strategis; dan } \\
\text { model proporsi. Hasil analisis Internal - Eksternal } \\
\text { menunjukkan bahwa strategi peningkatan PAD belum } \\
\text { didasarkan pada potensi dan peluang yang mereka } \\
\text { miliki. Pendapatan Pemerintah Daerah Kabupaten atau } \\
\text { Kota Padangsidimpuan memerlukan strategi intensifikasi } \\
\text { untuk meningkatkan PAD. Dengan analisis QSPM, } \\
\text { Pendapatan Pemerintah Daerah Kabupaten atau Kota } \\
\text { Padangsidimpuan perlu strategi ekstensifikasi untuk } \\
\text { penerimaan PAD. } \\
\text { Kata Kunci: Pendapatan Asli Daerah, Evaluasi Faktor } \\
\text { Internal, Evaluasi Faktor Eksternal, Matriks Perencanaan } \\
\text { Strategis. }\end{array}$ \\
\hline
\end{tabular}

\section{PENDAHULUAN}

Pelaksanaan otonomi daerah sesuai dengan ketentuan Undang-undang Nomor 23 Tahun 2014, menggariskan bahwa Pemerintah Daerah diberi kesempatan untuk menggali sumber sumber keuangan baru sesuai dengan potensi setempat. Penyelenggaraan otonomi daerah yang demikian ini mendorong terwujudnya kemandirian dari setiap daerah otonom. Kemandirian suatu daerah dapat terwujud apabila semua keperluan pembiayaan daerah baik pengeluaran rutin maupun pengeluaran pembangunan dapat dibiayai dengan kemampuan keuangan daerah. Secara makro, kemampuan keuangan daerah dapat dikaji dari sumbersumber penerimaan daerah yang tertuang dalam Anggaran Pendapatan dan Belanja Daerah (APBD).

Penerimaan daerah terdiri atas penerimaan yang berasal dari daerah sendiri (Pendapatan Asli Daerah/ PAD), penerimaan yang berasal dari Pemerintah Pusat dalam bentuk dana perimbangan, dan lain-lain pendapatan yang sah. (Halim, 2001) Sesuai dengan ketentuan yang ada dalam Undang-undang Nomor 32 Tahun 2004, setiap daerah memiliki 
kewenangan untuk mengoptimalkan penerimaan daerah yang berasal dari PAD yang terdiri atas pajak daerah, retribusi daerah, hasil perusahaan daerah dan hasil pengembalian kekayaan daerah. yang dipisahkan, serta lain-lain PAD yang sah (Muluk, 2003). Selama kurun waktu 5 Tahun terakhir, realisasi penerimaan PAD dan kontribusinya terhadap pendapatan daerah Kabupaten atau Kota Padang sidimpuan dapat disajikan dalam Tabel 1.

Tabel 1 PAD dan Kontribusi terhadap Penerimaan Daerah Kabupaten atau Kota Padang Sidimpuan tahun 2013-2017

\begin{tabular}{c|r|r|c}
\hline Tahun & \multicolumn{1}{|c|}{ PAD } & Pend. Daerah (Rp) & Kontribusi(\%) \\
\hline 2013 & $35.018 .219,52$ & $625.778 .532 .486,15$ & 6 \\
2014 & $58.725 .449 .619,94$ & $704.975 .445 .506,94$ & 8 \\
2015 & $67.730 .738 .637,98$ & $772.423 .223 .571,98$ & 9 \\
2016 & $78.417 .755 .706,26$ & $817.799 .713 .937,26$ & 10 \\
2017 & $109.640 .419 .280,55$ & $862.455 .261 .770,55$ & 13 \\
\hline
\end{tabular}

Berdasarkan data pada tabel tersebut dapat diketahui bahwa kenaikan PAD tidak seimbang dengan kenaikan pendapatan daerah, sehingga kontribusinya belum stabil. Kondisi ini antara lain disebabkan oleh strategi yang ditetapkan untuk penarikan PAD belum didasarkan pada kekuatan, peluang dan potensi yang ada di daerah seperti kerjasama lintassektor, komitmen pengelola PAD, standar pelayanan minimal dan sebagainya (Dewi, 2002). Rumusan masalah dalam penelitian ini yaitu apakah strategi peningkatan PAD sudah sesuai dengan potensi dan peluang yang ada di Kabupaten atau Kota Padang sidimpuan kemudian rumusan strategi apa yang paling tepat untuk meningkatkan PAD Kabupaten atau Kota Padang sidimpuan. Sedangkan alur pemikiran dalam penelitian :

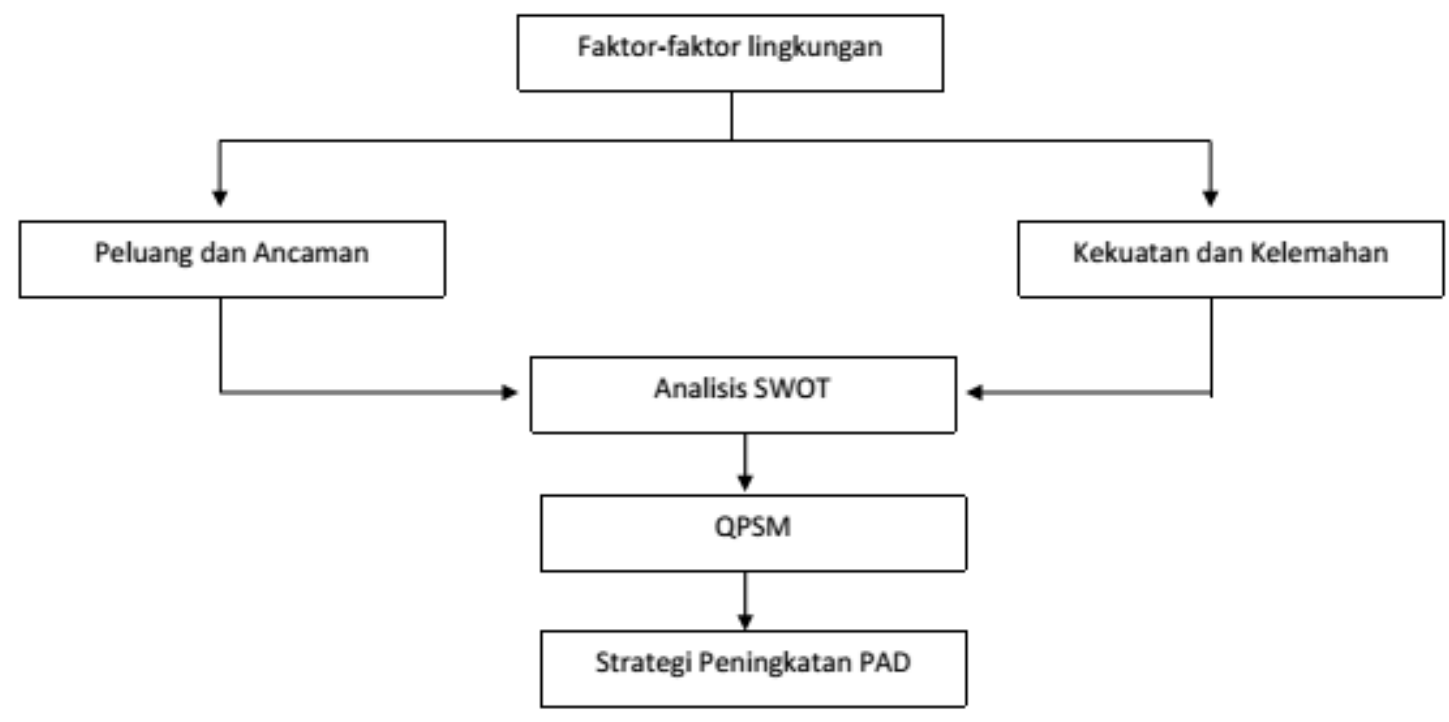

Gambar 1. Alur Pemikiran

\section{METODE PENELITIAN}

Pendekatan Quantitative Strategic Planning Matrix (QSPM) (David, 2001; Setiawan, 2005) sebagai dasar perumusan strategi peningkatan pendapatan daerah Kabupaten Batang. Penelitian ini merupakan sebuah penelitian deskriptif, yang dimaksudkan untuk melakukan pengukuran secara cermat terhadap fenomena yang ada tanpa harus menguji hipotesis. Penelitian ini dilakukan pada Badan Keuangan Daerah.

Variabel yang dioperasikan dalam penelitian ini dapat dijelaskan secara rinci tentang konsep variabel maupun indikator variabel sebagaimana disajikan dalam Tabel 2. 
Tabel 2 Jenis,Konsep, dan Indikator Variabel

\begin{tabular}{|c|c|c|}
\hline Jenis Variabel & Konsep Variabel & Indikator Variabel \\
\hline Pendapatan Daerah & $\begin{array}{l}\text { Hak Pemda yang diakui sebagai } \\
\text { penambah kekayaan bersih } \\
\text { dalam periode } \\
\text { bersangkutan }\end{array}$ & $\begin{array}{l}\text { 1. PAD } \\
\text { 2. Dana perimbangan } \\
\text { 3. Lain-lain pendapatan }\end{array}$ \\
\hline PAD & $\begin{array}{l}\text { Pendapatan yang bersumber } \\
\text { dari potensi yang ada di daerah } \\
\text { sendiri. }\end{array}$ & $\begin{array}{ll}\text { 1. } & \text { Pajak daerah } \\
\text { 2. Retribusi daerah } \\
\text { 3. Hasil pengelolaan } \\
\text { kekayaan daerah } \\
\text { 4. Lain-lain PAD yang } \\
\text { sah }\end{array}$ \\
\hline Kekuatan dan Kelemahan & $\begin{array}{l}\text { Faktor internal yang dapat } \\
\text { menambah atau mengurangi } \\
\text { kemampuan kinerja Badan } \\
\text { Keuangan Daerah }\end{array}$ & $\begin{array}{ll}\text { 1. } & \text { SDM } \\
\text { 2. } & \text { Lingkungan kerja } \\
\text { 3. } & \text { Prosedur / system } \\
\text { 4. } & \text { Saran / prasarana } \\
\text { 5. } & \text { Keuangan } \\
\text { 6. } & \text { Manajemen }\end{array}$ \\
\hline Peluang & $\begin{array}{lcc}\text { Faktor eksternal } & \text { yang } \\
\text { menguntungkan dan } & \text { dapat } \\
\text { dimanfaatkan oleh } & \text { Dinas } \\
\text { Pengelola Pendapatan } & \end{array}$ & $\begin{array}{ll}\text { 1. } & \text { Loyalitas obyek PAD } \\
\text { 2. Dukungan masyarakat } \\
\text { 3. Kerja sama lintas } \\
\text { sektor dan program } \\
\text { 4. } \\
\text { Dukungan yuridis }\end{array}$ \\
\hline Ancaman & $\begin{array}{l}\text { Faktor eksternal yang dapat } \\
\text { mengganggu kinerja Badan } \\
\text { Keuangan Daerah }\end{array}$ & $\begin{array}{ll}\text { 1. } & \text { Tuntutan mutu } \\
\text { pelayanan } \\
\text { 2. }\end{array}$ \\
\hline
\end{tabular}

\section{HASIL DAN PEMBAHASAN}

Hasil analisis yang dilakukan berdasar penilaian bobot, rating, dan skor setiap faktor lingkungan eksternal dan internal menunjukkan kondisi sebagaimana disajikan dalam tabel EFE dan IFE, IE matriks, SWOT matriks, dan QSPM yang secara berturutturut dijelaskan berikut ini.

1. Matrix External Factor Evaluation (EFE)

\begin{tabular}{|c|c|c|c|}
\hline \multicolumn{4}{|l|}{$\begin{array}{l}\text { External Key Factor } \\
\text { Peluang: }\end{array}$} \\
\hline Peluang: & & & \\
\hline $\begin{array}{l}\text { 1. loyalitas masyarakat terhadap adanya objek PAD } \\
\text { yang perlu dikembangkan }\end{array}$ & 0,080 & 4 & 0,320 \\
\hline 2. dukungan masyarakat sekitar objek PAD & 0,080 & 4 & 0,320 \\
\hline $\begin{array}{l}\text { 3. dukungan tokoh masyarakat terhadap pungutan } \\
\text { pajak dan retribusi }\end{array}$ & 0,080 & 3 & 0,240 \\
\hline 4. kerjasama lintas sektor & & & \\
\hline 5. kerjasama lintas program & 0,056 & 1 & 0,056 \\
\hline 6. kebijakan pemerintah daerah dalam peningkatan & 0,100 & 3 & 0,300 \\
\hline PAD & 0,100 & 4 & 0,400 \\
\hline Ancaman : & & & \\
\hline $\begin{array}{l}\text { 1. tuntutan terhadap mutu pelayanan pajak dan } \\
\text { retribusi }\end{array}$ & 0,051 & 1 & 0,051 \\
\hline 2. kurangnya kesadaran wajib pajak/retribusi & 0,120 & 4 & 0,0480 \\
\hline 3. kualitas SDM penarik pajak/retribusi & & & \\
\hline 4. situasi perekonomian & 0,121 & 4 & 0,484 \\
\hline 5. Pengaruh kebijakan politik pemerintah & 0,050 & 1 & 0,050 \\
\hline 6. Kurangnya ketersediaan biaya operasional & 0,060 & 4 & 0,240 \\
\hline 7. Pengaruh peraturan yang kurang konsisten dengan & 0,051 & 1 & 0,051 \\
\hline
\end{tabular}




\begin{tabular}{|l|c|c|c|}
\hline \multicolumn{1}{|c|}{ kondisi daerah } & 0,051 & 1 & 0,051 \\
& & & \\
\hline Total & 1,00 & & 3,043 \\
\hline
\end{tabular}

2. Matrix Internal Factor Evaluation (IFE)

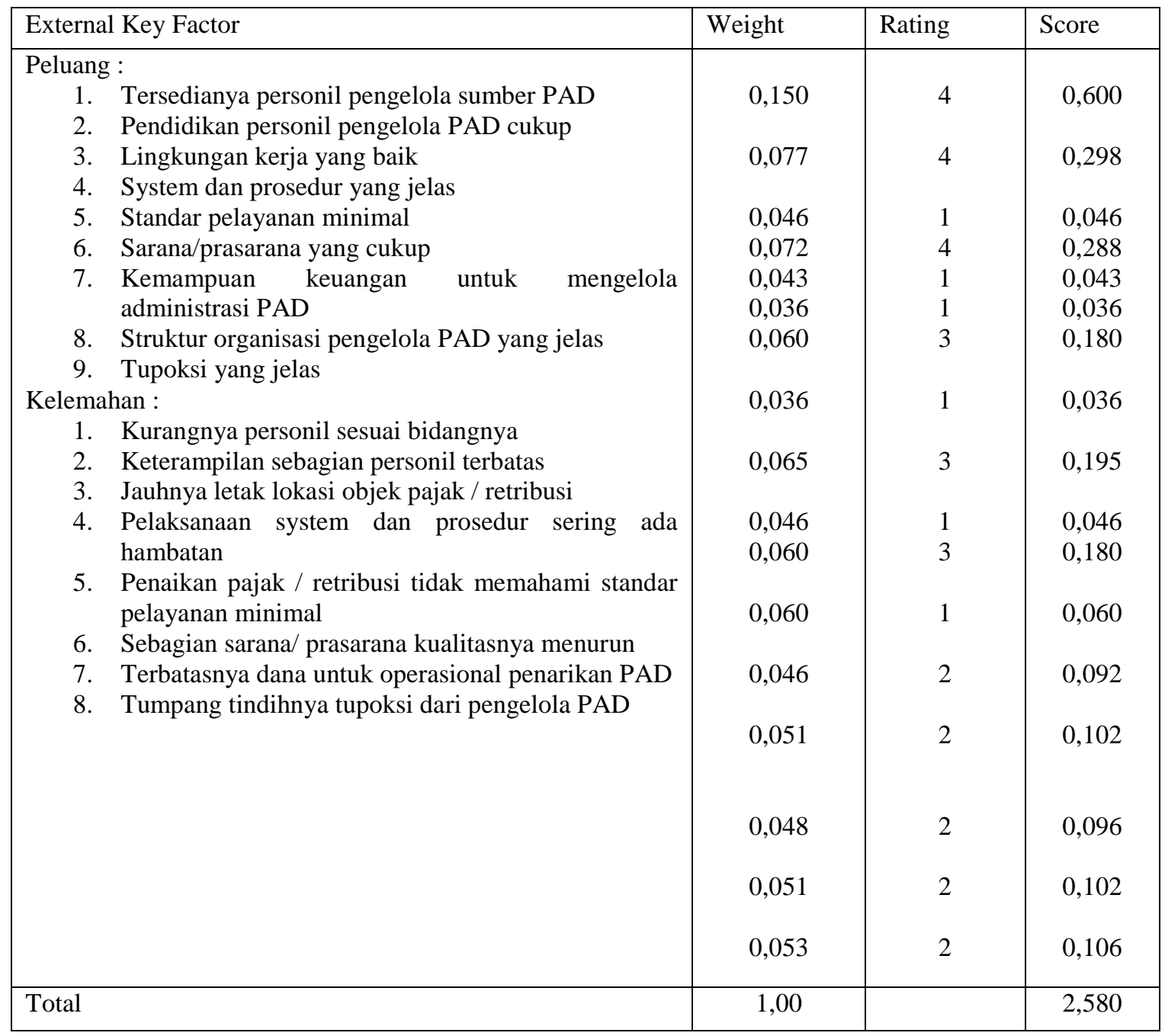

3. External dan Internal Matrix

Atas dasar analisis yang dilakukan terhadap faktor eksternal dan internal yang diringkas dalam matrik EFE dan IFE di muka, maka dapat disusun EI Matrix dengan mempertemukan nilai skor pada kedua matrix tersebut. Dengan demikian dalam matriks EI ini diperoleh perbandingan $\mathrm{EFE}:$ IFE $=3,043: 2,580$ jatuh pada sel I dan V. Hal ini mengandung arti bahwa Dipenda Kabupaten atau Kota Padangsidimpuan sebagai pengelola PAD perlu menerapkan strategi peningkatan PAD melalui EFE dan mempertahankan strategi melalui IFE.

\section{Analisis SWOT}

Hasil penjabaran dari matriks SWOT dapat dijelaskan keempat strategi berikut;

\section{Strategi SO:}

a. Meningkatkan loyalitas masyarakat dan pengelola PAD 

b. Meningkatkan kualitas pengelola PAD
c. Meningkatkan kerjasama lintassektor dan lintasprogram
d. Meningkatkan sinkronisasi program dan kegiatan sesuai Tupoksi
e. Menerapkan kebijakan standar pelayanan minimal

\section{Strategi WO:}
a. Menambah jumlah personil pengelola PAD
b. Meningkatkan ketrampilan pemungut pajak/retribusi
c. Memperbaiki kondisi lingkungan kerja dengan menerapkan sistem kerjasama antarbagian sektor
d. Menerapkan koordinasi dalam kebijakan pelaksanaan Tupoksi
e. Meningkatkan kemampuan keuangan untuk mengelola obyek PAD

\section{Strategi ST:}
a. Meningkatkan kualitas pelayanan dengan menerapkan standar pelayanan minimal
b. Sosialisasi sistem dan prosedur penarikan PAD
c. Menempatkan personil pemungut PAD sesuai dengan disiplin ilmunya
d. Meminimalkan pengaruh negatif kebijakan politik local
e. Sinkronisasi peraturan sesuai dengan potensi dan kondisi daerah

\section{Strategi WT:}
a. Meningkatkan kualitas SDM pemungut pajak/retribusi
b. Meningkatkan sarana mobilitas bagi pemungut pajak/retribusi
c. Meningkatkan koordinasi antarsektor dan bagian
d. Meningkatkan anggaran biaya operasional.

\section{Analisis QSPM}

Hasil pembobotan dan penilaian skor kemenarikan faktor strategis internal dan eksternal sebagai alternatif keputusan strategi terbaik yang harus segera dilaksanakan dalam analisis QSPM sebagai berikut :

Tabel 3. Matrix External Factor Evaluation (EFE)

\begin{tabular}{|c|c|c|c|}
\hline Strategic Key Factor & Weight & $\mathrm{AS}$ & TAS \\
\hline \multicolumn{4}{|l|}{ Kekuatan : } \\
\hline 1. Tersedianya personil pengelola sumber PAD & 0,150 & 3 & 0,450 \\
\hline 2. Pendidikan personal pengelola PAD cukup & & & \\
\hline 3. Lingkungan kerja yang baik & 0,077 & 3 & 0,231 \\
\hline 4. System dan prosedur yang jelas & & & \\
\hline 5. Standar pelayanan minimal & 0,046 & 2 & 0,092 \\
\hline 6. Sarana / Prasarana yang cukup & 0,072 & 3 & 0,216 \\
\hline 7. Kemampuan keuangan untuk mengelola & 0,043 & 2 & 0,086 \\
\hline administrasi PAD & 0,036 & 1 & 0,036 \\
\hline $\begin{array}{l}\text { 8. Struktur organisasi pengelola PAD yang } \\
\text { jelas }\end{array}$ & 0,060 & 2 & 0,120 \\
\hline 9. Tupoksi yang jelas & 0,036 & 1 & 0,036 \\
\hline \multicolumn{4}{|l|}{ Kelemahan : } \\
\hline 1. Kurangnya personil sesuai bidangnya & 0,065 & 3 & 0,195 \\
\hline 2. Keterampilan sebagian personil terbatas & & & \\
\hline 3. Jauhnya letak lokasi objek pajak/retribusi & 0,046 & 2 & 0,092 \\
\hline $\begin{array}{l}\text { 4. Pelaksanaan system dan prosedur sering ada } \\
\text { hambatan }\end{array}$ & 0,060 & 2 & 0,120 \\
\hline $\begin{array}{l}\text { 5. Penarik pajak /retribusi tidak memahami } \\
\text { standar pelayanan minimal }\end{array}$ & 0,060 & 2 & 0,120 \\
\hline $\begin{array}{l}\text { 6. Sebagian sarana/ prasarana kualitasnya } \\
\text { menurun }\end{array}$ & 0,046 & 2 & 0,092 \\
\hline
\end{tabular}




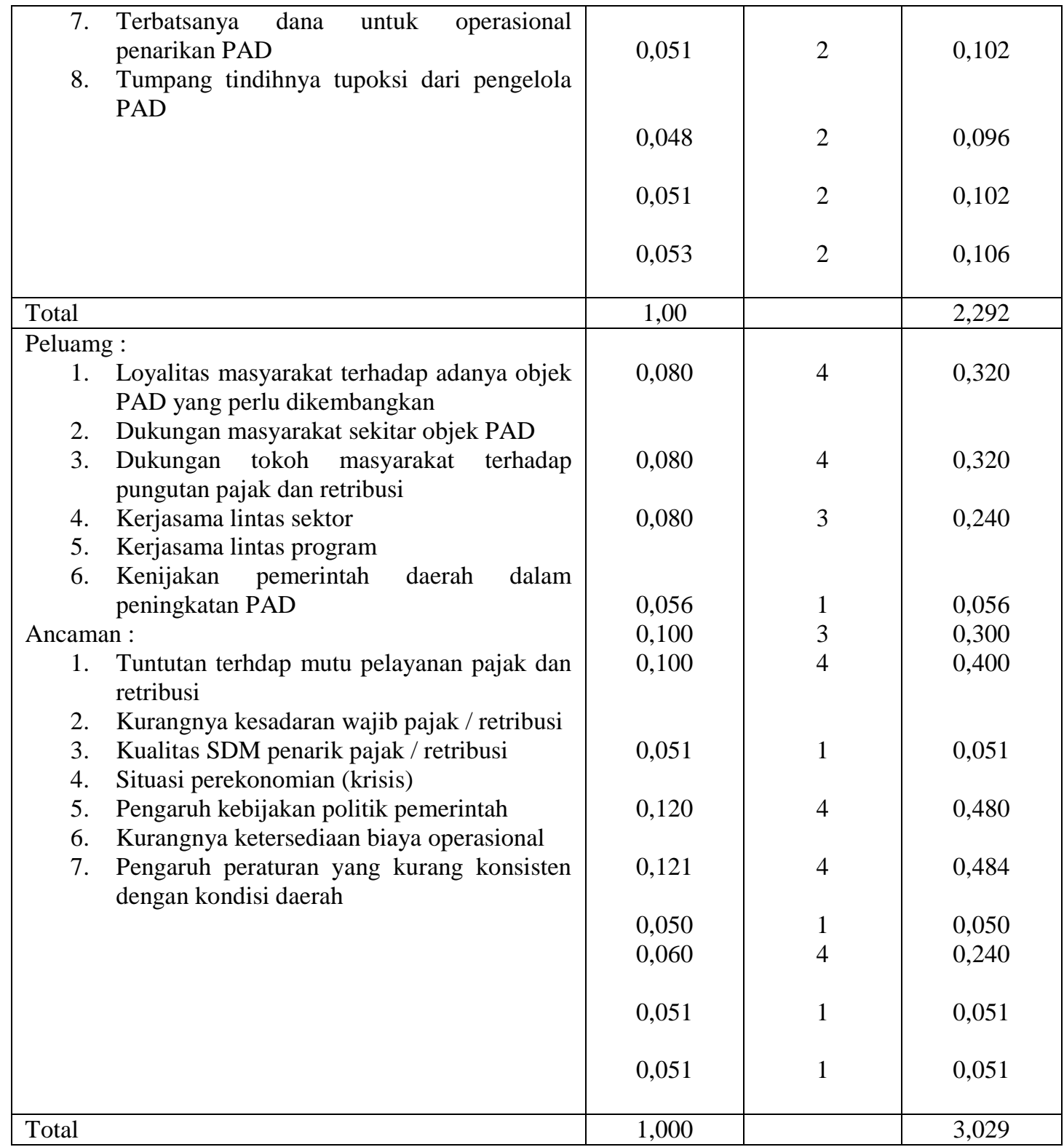

Hasil analisis terhadap skor kemenarikan dari semua faktor strategis yang dijelaskan dalam QSPM tersebut menunjukkan bahwa total skor kemenarikan (TAS) pada faktor eksternal $(3,029)$ adalah lebih besar dari TAS faktor internal $(2,292)$. Hal ini menunjukkan bahwa keputusan strategi yang tepat untuk meningkatkan PAD Kabupaten atau Kota Padangsidimpuan adalah dengan strategi ekstensifikasi. (Dianto, 2000) Kemudian pada daftar faktor strategis eksternal diperoleh nilai TAS terbesar pada kualitas pemungut pajak/retribusi $(0,484)$. Hasil ini mengindikasikan bahwa strategi ekstensifikasi yang dapat segera dilaksanakan secara lebih spesifik adalah strategi peningkatan kualitas SDM pemungut pajak/ retribusi daerah. Jadi, Dipenda Kabupaten atau Kota Padangsidimpuan dapat merumuskan keputusan strategi terbaik dari hasil analisis QSPM ini yakni untuk meningkatkan PAD pada masa mendatang dapat dilakukan strategi ekstensifikasi pada peningkatan kualitas SDM pemungut pajak/retribusi. 


\section{KESIMPULAN}

Setelah melakukan serangkaian analisis dengan pendekatan-pendekatan di muka, dapat ditarik simpulan dari penelitian ini, yakni:

1. Dari analisis IE matriks, diperoleh angka skor EFE 3,043 dan IEF 2,580 dan jatuh pada sel I dan V (sel pertumbuhan dan memelihara). Dengan demikian dapat disimpulkan bahwa upaya peningkatan PAD yang sekarang ini dilakukan oleh Dipenda Kabupaten atau Kota Padangsidimpuan belum sesuai dengan potensi dan peluang yang ada.

2. Jika dikonsultasikan dengan hasil analisis SWOT, kondisi pada simpulan 1 tersebut menunjukkan bahwa strategi yang digunakan sekarang belum sesuai dengan strategi SO, yaitu menggunakan kekuatan untuk memanfaatkan peluang.

3. Hasil analisis QSPM menunjukkan bahwa angka TAS pada faktor strategis eksternal sebesar 3,029 adalah lebih besar dibandingkan dengan angka TAS pada faktor strategis internal yakni sebesar 2,292. Angka ini menunjukkan bahwa strategis peningkatan PAD Kabupaten atau Kota Padangsidimpuan yang tepat untuk dilaksanakan adalah "strategis ekstensifikasi".

4. Keputusan strategi yang dapat segera dilaksanakan sesuai dengan skor kemenarikan setiap faktor strategis eksternal ternyata angka tertinggi ada faktor kualitas SDM pemungut pajak/retribusi $(0,484)$. Hal ini mengandung arti bahwa strategi eksternal yang spesifik untuk segera dilaksanakan adalah "strategi peningkatan kualitas SDM pemungut pajak/retribusi daerah.

\section{DAFTAR RUJUKAN}

David, Fred R., (2001). Strategic Management, Concept, and Cases, New Jersey: Prentice Hall.

Dewi, Elita, (2002). Identifikasi Sumber Pendapatan Asli Daerah dalam Rangka Pelaksanaan Otonomi Daerah, Makalah Seminar Digital Universitas Sumatera Utara.

Dianto, M. (2000). Upaya yang Dilakukan Daerah untuk Peningkatan PAD, Yogyakarta: Program Pascasarjana UGM.

Dyson, Robert G., (2003). Strategic Development and SWOT Analysis at the University of Warwick, European Journal of Operational Research Vol. 152, (3), 631-640.

Halim, Abdul, (2001). Manajemen Keuangan Daerah, Yogyakarta: UPP AMP YKPN

Mooney, Dick, (2001). SWOT Analysis - A Structured Way to Plan, Communicator, Vol. 2 (4).

Muluk, Khairul, (2003). Kinerja Lima-E, Keuangan Publik, Jurnal Forum Inovasi, Vol 1(2), Jakarta.

Sarkis, Joseph, (2003). Quantitative Models for Performance Measurement Systems Alternate Considerations (Quantitative Strategic Planning Matrix/QSPM). International Journal of Production Economics. Vol. 86, (1), 81-90.

Setiawan, Rudie (2005) Perumusan Strategi Bisnis dengan Menggunakan Metode QSPM (Quantitative Strategic Planning Matrix): Studi Kasus pada Hotel " $X$ " di Bandung, Tesis Magister Manajemen Bisnis dan Administrasi Teknologi. Bidang Khusus Bisnis Manufaktur, Bandung. 